\title{
PERBEDAAN SELF CONFIDENCE SISWA ANTARA CREATIVE PROBLEM SOLVING DAN DISCOVERY LEARNING DITINJAU DARI GENDER
}

\author{
Ahmad Isnaini ${ }^{1)}$, Edy Surya ${ }^{2)}$ \\ ${ }^{1)}$ SMA Dr Wahidin Sudirohusodo, Jl. K.L. Yos Sudarso Km 16,5, Medan, ahmadisnaini22@gmail.com \\ 2) Universitas Negeri Medan, Jl. Willem IskandarV, Medan,edy_surya71@yahoo.com
}

\begin{abstract}
Abstrak. Penelitian ini bertujuan untuk melihat perbedaan self confidence siswa antara siswa yang diajarkan dengan model pembelajaran creative problem solving dan model pembelajaran discovery learning jika ditinjau dari gender. Analisis data hasil penelitian menggunakan Anava dua jalur dengan jumlah sel yang tidak sama untuk melihat pengaruh gender dan model pembelajaran terhadap self confidence siswa. Setelah ditemukan pengaruh gender dan model pembelajaran, dilakukan uji lanjut pasca Anava menggunakan metode Scheffe'. Hasil yang diperoleh antara lain sebagai berikut: Terdapat pengaruh gender terhadap self confidence siswa, terdapat pengaruh model pembelajaran terhadap self confidence siswa, tidak terdapat interaksi antara gender dan model pembelajaran terhadap self confidence siswa dan dengan uji lanjut pasca Anava dengan metode Scheffe', diperoleh hasil bahwa terdapat perbedaan self confidence antara model creative problem solving dengan model discovery learning. Siswa perempuan memiliki self confidence yang lebih baik dari siswa lelaki dan model pembelajaran creative problem solving memberikan hasil self confidence yang lebih baik dari pada model discovery learning.
\end{abstract}

Kata Kunci. Creative Problem Solving, Discovery Learning, Self Confidence

\section{Students' Self Confidence Difference Between Creative Problem Solving and Discovery Learning Based on Gender}

\begin{abstract}
This study aims to see the differences in students' self confidence between students with the treatment of the creative problem solving learning model and the discovery learning model analysed based on gender. The data analysis was done using two-way Anava with different number of cell to see the effect of gender and learning models on students' self confidence. After the effect of gender and the learning model was found, a further post-Anova test using Scheffe method was executed. This analysis shows the following results: gender has an influence on students' self confidence as well as there is an influence of the learning model on students' self confidence, there is no interaction between gender and learning models on students' self confidence. When a post-Anova test with Scheffe's method was applied, it is found that there are differences in students' self confidence between the creative problem solving model and the discovery learning model. Female students have better self confidence than male students, while the creative problem solving model provides better self confidence than discovery learning model.
\end{abstract}

Keywords. Creative Problem Solving, Discovery Learning, Self Confidence 


\section{Pendahuluan}

Self confidence merupakan anggapan seseorang mengenai kesanggupan - kesanggupannya dalam menghadapi berbagai hal. Terkait matematika, McLeod (Hasibuan \& Surya, 2018) mengungkapkan bahwa rasa percaya diri merupakan keyakinan tentang kompetensi diri dalam matematika dan kemampuan seseorang dalam matematika yang merupakan hasil dari proses belajar dan berlatih mengerjakan soal-soal matematika.

Perlunya self confidence dimiliki siswa dalam belajar matematika ternyata tidak dibarengi dengan fakta yang ada. Hasil dari TIMMS (Eviyanti, 2017) menyatakan dalam skala internasional hanya $14 \%$ siswa yang memiliki self confidence tinggi terkait kemampuan matematikanya. Sedangkan $45 \%$ siswa termasuk dalam kategori sedang, dan $41 \%$ sisanya termasuk dalam kategori rendah. Hal serupa terjadi pada siswa di Indonesia. Hanya 3\% siswa yang memiliki self confidence tinggi dalam matematika, sedangkan $52 \%$ termasuk dalam kategori siswa dengan self confidence sedang dan $45 \%$ termasuk dalam kategori siswa dengan self confidence rendah.

Pengembangan self confidence di sekolah masih belum tampak. Hal ini didukung oleh fakta yang dikemukakan oleh Rohayati (2011), yaitu masih banyak siswa Indonesia kurang memiliki rasa percaya diri. Siswa akan merasa gugup dan tegang jika dihadapkan pada masalah. Sesungguhnya, masalah self confidence merupakan masalah psikologi yang menjadi tugas dari guru bimbingan konseling (BK). Guru bimbingan konseling (BK) harus melakukan usaha untuk meningkatkan rasa percaya diri siswa. Namun jumlah guru BK saat ini sangat kurang. Dari satu sekolah terkadang guru BK hanya ada satu untuk siswa lebih dari dua ratus. Padahal standar guru BK satu guru untuk seratus siswa. Kurangnya guru BK menyebabkan penanganan masalah psikologi, termasuk masalah rendahnya self confidence, di sekolah masih jauh dari harapan.

Preston (2007) mengungkapkan ada 5 aspek pembangun kepercayaan diri yaitu: selfawarenes, niat, pemikiran, imajinasi, dan akting 'seolah-olah (Rusmini, Surya, 2017). Terkait dengan matematika, Margono (2005) mengungkapkan bahwa kepercayaan diri siswa dalam pembelajaran matematika dapat dibagi menjadi tiga aspek, yaitu: (1) kepercayaan pada pemahaman dan kesadaran diri terhadap kemampuan matematika, (2) kemampuan diri untuk menentukan secara realistis sasaran yang ingin dicapai dan rumuskan rencana aksi sebagai upaya untuk mencapai tujuan, (3) kepercayaan pada matematika itu sendiri. Keyakinan diri sangat penting bagi siswa untuk berhasil dalam belajar matematika. Pembentukan kepercayaan diri siswa dalam pembelajaran matematika merupakan proses yang kompleks, termasuk interaksi dengan beberapa faktor seperti: keluarga, sosialisasi, pengalaman sekolah, budaya, usaha meraih sasaran, serta kepercayaan terhadap matematika itu sendiri.

Faktor lain yang juga dapat berkontribusi terhadap self confidence siswa dalam pembelajaran matematika adalah gender, yang membagi siswa ke dalam dua kelompok yakni kelompok siswa pria dan kelompok siswa wanita. Selain faktor strategi pembelajaran, faktor gender juga mempengaruhi hasil belajar matematika. Hardy, Hudiono, Rajiin (2014) menyatakan 
siswa perempuan cenderung memiliki motivasi rendah dalam belajar matematika dari pada siswa laki-laki. Hal tersebut dipengaruhi oleh belahan otak kanan siswa laki-laki mempunyai kemampuan yang lebih kuat di bidang numerik dan logika dari pada belahan otak kanan siswa perempuan. Sedangkan belahan otak kiri siswa perempuan mempunyai kelebihan di bidang estetika dan religius dari pada belahan otak kiri siswa laki-laki. Intelegensi yang tinggi pada perempuan cenderung tidak pernah mempunyai ketertarikan yang menyeluruh pada soal-soal teoritis seperti laki-laki. Perempuan lebih dekat pada masalah-masalah kehidupan yang praktis dan konkret, sedangkan laki-laki lebih tertarik pada segi-segi yang abstrak (Firman, dkk, 2013). Menurut Susento (2006), perbedaan gender bukan hanya berakibat pada perbedaan kemampuan dalam matematika, tetapi cara memperoleh pengetahuan matematika. Keitel (1998) menyatakan "gender, social, and cultural dimensions are very powerfully interacting in conceptualization of mathematics education,...". Berdasarkan pendapat Keitel bahwa gender, sosial dan budaya berpengaruh pada pembelajaran Matematika.

Goos (Prayitno, Sudi, Suwarsono, Siswono, 2013) menyebutkan bahwa banyak hasil penelitian terkini yang menyajikan adanya perbedaan prestasi belajar, sikap, dan partisipasi yang dipengaruhi perbedaan faktor gender (Pane, N., Syahputra, \& Mulyono, 2018). Para peneliti saat ini menyadari bahwa perbedaan hasil belajar matematika siswa yang dipengaruhi perbedaan gender adalah tidak mutlak, sering tertukar, hal ini juga dipengaruhi latar belakang sosial ekonominya. Menurut Rushton (Amir, 2013) menjelaskan bahwa perbedaan prestasi belajar laki-laki dan perempuan lebih disebabkan oleh perbedaan tingkat inteligensi. Laki-laki lebih aktif dari pada perempuan. Akan tetapi, keaktifan laki-laki ini kemudian menyebabkan laki-laki menjadi lebih sulit untuk diatur. Hal inilah yang menyebabkan laki-laki memiliki prestasi belajar yang lebih rendah daripada perempuan. Sedangkan pada aspek kepercayaan diri, perempuan yang lebih baik daripada laki-laki dalam menyelesaikan tugas-tugas belajarnya, turut mendukung prestasi pendidikannya.

Hasil penelitian Ekasari (2017) ditinjau dari gender menyimpulkan: (a) siswa laki-laki lebih mampu mengekspresikan ide matematika secara lisan sedangkan siswa perempuan lebih mampu mengekspresikan ide matematika secara visual dan tertulis; (b) siswa laki-laki dan perempuan keduanya sama-sama mampu memahami, mengintepretasikan dan mengevaluasi ide matematika baik secara lisan; (c) siswa laki-laki lebih mampu mengambarkan hubunganhubungan dan model-model situasi, sedangkan siswa perempuan lebih mampu dalam menggunakan istilah-istilah dan notasi-notasi.

\section{Metodologi}

Desain penelitian ini adalah Postest Only NonEquivalent Multiple Group Design (Wiersma \& Jurs, 2009). Variabel bebas dalam penelitian ini adalah gender dan model pembelajaran, sementara yang menjadi variabel terikat adalah self confidence siswa.

Penelitian dilakukan di SMA Dr Wahidin Sudirohusodo Medan pada 23 April 2019 sampai 03 Mei 2019. Populasi penelitian adalah seluruh siswa kelas X di SMA tersebut, dan diambil secara acak dua kelas sebagai kelas eksperimen, yakni kelas X MIA 2 untuk kelas dengan pembelajaran model creative problem solving dan kelas X MIA 3 untuk kelas dengan 
pembelajaran model discovery learning. Kedua kelas memiliki jumlah siswa yang sama yakni sebanyak 36 siswa pada satu kelas.

Kedua kelas eksperimen tersebut dilakukan pembelajaran sesuai model pembelajaran masing-masing. Untuk teknis pengumpulan data dilakukan dengan pemberian postes self confidence yakni dengan instrumen pengumpulan data berupa angket dengan skala likert yang telah diuji validitasnya.

Data hasil postes Self Confidence, dianalisis dengan menggunakan uji Anava dua jalur, dengan terlebih dahulu dilakukan uji normalitas data dan uji homogenitas data sebagai syarat untuk uji Anava dua jalur.

Analisis data pada penelitian ini adalah didasarkan terhadap gender, dimana pada kedua kelas sampel, siswa laki - laki dan siswa perempuan tidak memiliki jumlah siswa yang sama, maka dilakukan uji Anava dua jalur dengan jumlah sel yang tidak sama. Uji Anava dilakukan untuk melihat terdapatnya pengaruh variabel bebas penelitian terhadap variabel terikat pada penelitian ini. Perhitungan dilakukan menggunakan SPSS.

Setelah diketahui terdapat pengaruh antara gender dan model Pembelajaran, bahkan interaksi keduanya terhadap self confidence, selanjutnya dilakukan uji lanjut pasca Anava, yakni dengan menggunakan metode Scheffe, dimana dilakukan uji komparasi antar baris, uji komparasi antar kolom dan uji komparasi antar sel pada baris dan kolom yang sama. Uji komparasi dengan metode Scheffe' ini dilakukan untuk melihat perbedaan yang terjadi (Budiyono, 2009).

\section{Hasil dan Diskusi}

Hasil dari data postes self confidence sebelum dianalisis menggunakan Anava Dua Jalur, harus terlebih dahulu diuji normalitas dan homogenitas data sebagai syarat uji anava. hasil uji homogenitas data, disajikan dalam Tabel 1 berikut:

Tabel 1. Uji Normalitas Data Postes Self Confidence Siswa

\begin{tabular}{|l|l|l|l|}
\hline Kelas & $\mathrm{N}$ & $\mathrm{D}_{0}$ & $\mathrm{D}_{\text {tabel }}$ \\
\hline CPS & 36 & 0,167 & 0,224 \\
\hline DL & 36 & 0,099 & 0,224 \\
\hline
\end{tabular}

Dari data diperoleh nilai $\mathrm{D}_{0}<\mathrm{D}_{\text {tabel }}$ yang mengakibatkan, data postes self confidence dari kedua kelas eksperimen berdistribusi normal. Selanjutnya dilakukan uji Homogenitas Varians postes self confidence yang disajikan dalam Tabel 2 berikut:

Tabel 2. Uji Homogenitas Varians Postes self confidence Siswa

\begin{tabular}{|l|c|c|c|}
\hline \multicolumn{1}{|c|}{ Kelas } & Varians $\left(\mathrm{s}^{2}\right)$ & $\mathrm{F}_{\text {hitung }}$ & $\mathrm{F}_{\text {tabel }}$ \\
\cline { 1 - 2 } CPS & 34,535 & 1,425 & 1,757 \\
\cline { 1 - 2 } DL & 24,229 & & \\
\hline
\end{tabular}

Berdasarkan Tabel 2 di atas diperoleh bahwa nilai $F_{\text {hitung }}<F_{\text {tabel, }}$ yang berarti kedua data homogen. Setelah kedua syarat awal untuk uji Anava Dua Jalur terpenuhi, selanjutnya kita menguji data menggunakan SPSS. Hasilnya disajikan dalam Gambar 1 berikut: 


Tests of Between-Subjects Effects
Dependent Variable: Self_Confidence
\begin{tabular}{|l|r|r|r|r|r|}
\hline Source & \multicolumn{1}{|c|}{$\begin{array}{r}\text { Type III Sum } \\
\text { of Squares }\end{array}$} & df & Mean Square & F & Sig. \\
\hline Corrected Model & $357.861^{\text {a }}$ & 3 & 119.287 & 4.420 & .007 \\
Intercept & 299743.285 & 1 & 299743.285 & 11107.571 & .000 \\
Model & 149.832 & 1 & 149.832 & 5.552 & .021 \\
Gender & 117.008 & 1 & 117.008 & 4.336 & .041 \\
Model * Gender & 103.696 & 1 & 103.696 & 3.843 & .054 \\
Error & 1835.014 & 68 & 26.985 & & \\
Total & 303669.000 & 72 & & & \\
Corrected Total & 2192.875 & 71 & & & \\
\hline
\end{tabular}

a. R Squared $=.163$ (Adjusted R Squared $=.126$ )

Gambar 1. Konfirmasi Perhitungan Anava menggunakan SPSS

Dari Gambar 1 diperoleh hasil antara lain, pengaruh model Pembelajaran terhadap self confidence memiliki signifikansi 0,021. Karena sig. $<0,05$, artinya terdapat pengaruh model terhadap self confidence siswa.

Hasil yang sama diungkapkan oleh Eviyanti (2017) dalam penelitiannya. Eviyanti menyimpulkan rata-rata $N$-Gain skor skala self confidence kelas eksperimen 0,395 sedangkan $N$-Gain rata-rata skor hasil penelitian untuk kelas kontrol 0,287. Rusmini, Surya, 2017, menyatakan bahwa skor rata - rata self confidence siswa adalah 80,21 sedangkan skor rata - rata self confidence siswa kelas kontrol adalah 76,35. Hal ini menunjukkan bahwa model pembelajaran memiliki pengaruh terhadap self confidence siswa.

Pada pengaruh gender, nilai Sig. 0,041 $<0,05$, artinya terdapat pengaruh gender terhadap self confidence siswa. Hasil yang sama diperoleh Pane, N., Syahputra, \& Mulyono, 2018, yakni self confidence siswa lelaki yang diajarkan dengan model MEAs lebih baik dari pada siswi perempuan. Artinya gender memiliki pengaruh terhadap self confidence siswa.

Sedangkan pada pengaruh Interaksi bersama antara model Pembelajaran dan gender terhadap self confidence siswa, nilai Sig. 0,054>0,05, yang berarti tidak terdapat Interaksi antara model Pembelajaran dan gender terhadap self confidence siswa.

Karena terdapat pengaruh antara model Pembelajaran dan gender terhadap self confidence siswa, langkah selanjutnya adalah melihat perbedaan self confidence siswa dengan mengunakan Metode Scheffe'. Hasil rataan antar sel disajikan dalam Tabel 3 berikut:

Tabel 3. Rataan Antar Sel

\begin{tabular}{|c|c|c|c|c|}
\hline \multirow{2}{*}{ gender } & \multicolumn{2}{|c|}{ model Pembelajaran } & Ukuran & Rerata \\
\cline { 2 - 5 } & CPS & DL & Sampel & Marginal \\
\hline Laki - Laki & 63,74 & 63,25 & 35 & $\mathbf{6 3 , 4 9}$ \\
\hline Perempuan & 68,71 & 63,40 & 37 & $\mathbf{6 6 , 0 5}$ \\
\hline Ukuran Sampel & 36 & 36 & & \\
\hline Rerata Marginal & $\mathbf{6 6 , 2 2}$ & $\mathbf{6 3 , 3 3}$ & & 64,773 \\
\hline
\end{tabular}


Uji komparasi antar baris dengan metode Scheffe' untuk melihat perbedaan kedua model pembelajaran terhadap self confidence siswa, memiliki hasil antara lain, dapat disimpulkan adanya perbedaan rerata self confidence yang signifikan antara gender laki - laki dan gender perempuan. Berdasarkan Tabel 3 di atas, rerata marginal untuk gender laki - laki adalah 63,49 dan gender perempuan adalah 66,05, sehingga dapat disimpulkan bahwa gender perempuan memberikan kemampuan self confidence yang lebih baik dari pada gender laki laki.

Uji komparasi antar kolom dengan metode Scheffe' untuk melihat perbedaan kedua model pembelajaran terhadap self confidence siswa, memiliki hasil antara lain, dapat disimpulkan adanya perbedaan rerata self confidence yang signifikan antara model pembelajaran creative problem solving dan model pembelajaran discovery learning. berdasarkan tabel 3 di atas, rerata marginal untuk model pembelajaran creative problem solving adalah 66,22 dan model pembelajaran discovery learning adalah 63,33, sehingga dapat disimpulkan bahwa model pembelajaran creative problem solving memberikan self confidence yang lebih baik dari pada model pembelajaran discovery learning.

Uji komparasi antar sel pada baris yang sama dan pada kolom yang sama tidak perlu dilakukan dikarenakan pada hasil uji anava, tidak ditemukannya interaksi antara model pembelajan dan gender terhadap self confidence siswa.

\section{Kesimpulan}

Berdasarkan Gambar 1, diperoleh beberapa kesimpulan antara lain, model pembelajaran baik model creative problem solving dan discovery learning yang digunakan sebagai model pembelajaran pada kedua kelas eksperimen berpengaruh terhadap self confidence siswa, gender juga memiliki pengaruh terhadap self confidence siswa, dan tidak terdapat interaksi antara model pembelajaran dan gender terhadap self confidence siswa antara kedua model pembelajaran jika ditinjau dari gender. Berdasarkan Tabel 3, diperoleh beberapa kesimpulan antara lain, terdapat perbedaan self confidence siswa antara kedua model pembelajaran jika ditinjau dari gender. Siswa perempuan memiliki self confidence yang lebih baik dari siswa laki - laki dan model pembelajaran creative problem solving menumbuhkan self confidence siswa yang lebih baik dari pada model discovery learning.

\section{Daftar Pustaka}

Amir, Z. (2013). Persfektif Gender dalam Pembelajaran Matematika. Jurnal Marwah Vol. XII No. 1 Juni Th. 2013, pp 14-31

Budiyono . (2004). Statistika untuk Penelitian. Surakarta: Sebelas Maret University Press

Ekasari, D. F. (2017). Kemampuan Komunikasi Matematika Siswa Ditinjau dari Gender Kelas VII SMP Negeri 2 Kembang Tahun Ajaran 2016/2017. Skripsi, Tidak Diterbitkan

Eviyanti, C. Y. (2017). Perbedaan Peningkatan Kemampuan Reprsentasi Matematis dan Self Confidence Siswa pada Pembelajaran Berbasis Masalah dan Pembelajaran Biasa di SMPN 1 Lhokseumawe. Tesis, UNIMED, Tidak Diterbitkan

Firman, dkk. (2013). Pengaruh Persepsi Matematika Terhadap Hasil Belajar Matematika Ditinjau dari Perspektif Gender Siswa Kelas V SD Negeri di Kecamatan Pasonggsongan Kabupaten Sumenep. Jurnal Universitas Wiraraja. 
Hardy; Hudiono; Rajiin. (2015). Pengaruh Gender dan Strategi Pembelajaran Terhadap Kemampuan Pemecahan Masalah Matematis Siswa. Jurnal Pendidikan dan Pembelajaran Khatulistiwa. UNTAN Pontianak, Vol 4 No. 9

Hasibuan; Aisyah; Surya. (2018). Pengaruh Pendekatan Problem Solving Terhadap Kemampuan Komunikasi Matematis dan Self Confidence Siswa di SMA Padangsidimpuan, www.researchgate.net

Keitel, Christine. (1998). Social Justice and Mathematics Education Gender, Class, Ethnicity and the Politics of Schooling. Berlin: Freie Universität Berlin

Margono, S. (2005), Metodologi Penelitian Pendidikan. Jakarta: PT.Rineka Cipta

Pane, N; Syahputra; Mulyono. (2018). Improving the Ability of Creative Thinking Mathematically and Self-Confidence Student through Application Model Eliciting Activities (MEAs) Review from Student Gender. American Journal of Educational Research 2018, Vol. 6, No. 4, 319-323

Prayitno, Sudi; Suwarsono; Siswono. (2013). Komunikasi Matematis Siswa SMP dalam Menyelesaikan Soal Matematika Berjenjang Ditinjau dari Perbedaan Gender. Prosiding Seminar Nasional Matematika dan Pendidikan Matematika UNY 2013

Preston, D. L. (2007). 365 Steps To Self Confidence. ISBN: 978 184803210. Oxford OX5 IRX

Rohayati, I. (2011). Program Bimbingan Teman Sebaya Untuk Meningkatkan Percaya Diri Siswa. Jurnal Penelitian Pendidikan UPI, Edisi Khusus No 1 Agustus 2011, pp 368 - 376

Rusmini, Surya. (2017). The Effect of Contextual Learning Approach to Mathematical Connection Ability and Student self confidence Grade VIII SMP Negeri 8 Medan. International Journal of Sciences: Basic and Applied Research (IJSBAR) ISSN 2307-4531

Susento. (2006). Mekanisme Interaksi Antara Pengalaman Kultural-Matematis, Proses Kognitif, dan Topangan dalam Reivensi Terbimbing. Disertasi. Surabaya: UNESA

Wiersma ; Jurs . (2009). Research Methods in Education An Introduction (9th Edition). The University of Toledo 